\title{
THE AESTHETIC AND FUNCTIONAL RELATIONSHIP OF THE MINERAL GATHERING IN ISLAMIC ART
}

Sherif Massad Muhammad AREF *

Department of Artistic Works and Folklore, Faculty of Technical Education, Helwan University, Egypt

\begin{abstract}
An important criterion for Islamic art is the integration of the Muslim artist and maker for a collective need And his environment for this was the formative criterion for research is the means that enables him to know the appearances of beauty It shows through it the extent of expressive interaction in its artifacts, which is confirmed by Herbert Read, dividing the activity, The original artistic to different styles, including expression, utilitarian and aesthetic purpose. Among the domains and handicrafts of Islamic art, the masterpieces of the artist and the maker appear Muslim is the art of metalworking, especially in metal gathering, as its shapes and sizes varied as well The type of metal used in the formation and performance methods with different tools, and the methods of treatment came The surface of these artifacts is in various forms of recessed, protruding, drilling, slitting, hollowing and bonding And the use of different colors of enamel.

Keywords

The Aesthetic, Functional Relationship, The Mineral Gathering, Islamic Art.
\end{abstract}

\section{Introduction}

For enamel ... and others used occasionally in single cases, both (plants And various lines, some animals, and some people's drawings) and at other times he was able to mix between More than one shape in the same workpiece, so he was able, with his ability to mix between the geometric and organic form in One entity, and the design of these artifacts was related to the shape of the buildings, both from the inside and outside.

Perhaps one of the factors that helped the progress of the metal industry and flourish is passion and love Princes and sultans, and upon him are the collectors of antiques and metal valuables, and the possession of valuables.

Al-Maqrizi, "his famous saying, a house in Cairo and Egypt is hardly empty of many cuffed copper pieces. Or the presence of some foreigners in Egypt and their establishment of various handicrafts and the exchange of technical expertise Between Egypt and neighboring countries, or through the migration of skilled craftsmen from Mosul to Egypt after the invasion The Mongolians to Cairo, the importance of studying the heritage in general, especially the handicrafts is something that develops belonging Perhaps the field of Islamic mineral collection is an important and worthy study Heritage study. By learning it, a person can understand the present and distinctive role of this nation, and look at the heritage Not for the purpose of simulation and imitation, but rather to research its folds, ideological and philosophical foundations, and the consistency of structural systems To find solutions to what we are looking

* Corresponding author: education@helwan.edu.eg 
for, with the aim of absorbing the values that enrich our self-balance, then we can employ To find solutions to what we are looking for, with the aim of absorbing the values that enrich our self-balance, then we can employ Collection technology in new and modern crafts that productive families can benefit from financially to increase Income.

It is also possible to activate tourism internally and externally, and also benefit in small projects.

For young people, in a way that reduces unemployment, achieves a utilitarian and national return, and finally revives the cultural heritage of one of the Traditional industries in Islamic art. Therefore, the research problem is defined in the following question:

\section{Research Problem:}

How can the Islamic metal collection operations be used as one of the traditional industries in $\operatorname{art?}$

Al Islami to do modern crafts?

Research hypotheses:

Through metal collection operations, plastic and aesthetic solutions can be found that contribute to revival

Cultural heritage of a traditional industry in Islamic art.

research aims:

- A statement of the aesthetic and functional value of one of the areas of the traditional heritage industries, which is shaping.

By metallic plural in Islamic art.

- The possibility of employing the collection method in the artifacts of its use inside and outside the home with new perspectives.

- Take advantage of the collection method in projects that serve productive families, and small enterprises.

Activation of tourism, internally and externally.

\section{Research Importance:}

- Shedding light on a metal formulation method by which the beneficial return can be achieved For the community.

Demonstrate the importance of reviving the cultural heritage of traditional industries in Islamic art.

- Finding entrances to create metalwork based on the intellectual and philosophical foundations of Islamic art Combine.

Research contributes to the development of the innovation capacity by identifying the plastic 
and aesthetic capabilities

For metallic combination.

\section{Results and Recommendations:}

\section{- Results}

1- Interest in studying Islamic art and uncovering the philosophy of the accompanying thought and establishing relationships Technical.

2- The development and refinement of the innovative capacity, the aesthetic taste and the sense of national belonging.

3- Through the study of the technical and artistic methods of metalwork, many Small projects for productive families, in order to achieve economic returns and eliminate unemployment.

4- It is possible to benefit from the Islamic heritage in metal gathering to make crafts suitable for souvenirs Tourism.

5- Investing in various materials such as glass, beads, ceramics and wood, along with metalwork Because of their functional and aesthetic role, the modern artist benefited from them in a distinctive way.

6- There are some ways in which shapes can be constructed by metallic assembly by means of pistons And work as much my productivity in less time and less effort.

\section{Recommendations}

1- It is necessary to study the national heritage in order to clarify the intellectual and philosophical foundations behind every art to find out Modern starting points that stem from understanding and awareness.

2- Paying attention to handicrafts, especially in the field of metalworking, due to its high value that can be used Including the benefits of families and small projects and reduce unemployment, as well as in the work of publicity Tourism, which increases the national income.

3- Carrying out seminars, conferences and magazines to show the impact of heritage, especially handicrafts and industries, and how

Preserve it.

4- Establishing centers to train youth on handicrafts for their benefit.

5- Working a day to market handicrafts at the republic level and building civil society institutions with Various bodies and institutions that.

6- Metals such as tin and aluminum can be used to reduce the cost and use of coatings after that to raise and maintain its nominal value. 


\section{References}

1- Abu Salih Al-Alfi 1990 “Islamic Art: Its Origins, Philosophy, and Study”, Dar Al Ma'arif, Lebanon.

2- Ahmed Hafez Hassan 1985: Benefiting from the artistic and technical values of Egyptianowned metalwork

In the work of innovative crafts, "unpublished $\mathrm{PhD}$ thesis, Art Education, Helwan University

3- Ansar Muhammad Awad 1996, the content of my expression of Islamic art and its educational philosophy, a letter

Unpublished Master, Faculty of Technical Education, Helwan University.

4 Al-Maqrizi "Without the year of publishing" Plans and Archeology in Egypt, Cairo, and the Nile, and related news

C2, Cairo, Bulaq Press.

5- Ulker Argen Sawy, translated by Al-Safsafi Ahmad Al-Qatouri 2005 The evolution of the Islamic art of metallurgy,

The Supreme Council of Culture, Al-Jazeera, Cairo.

6- Sherif Aref, Afifi, Abeer Muhammad 2016: Synthesis with Environmental and Consumer Materials, 1st Edition.

Dar Al-Andalus for Distribution and Publishing, Hail, Kingdom of Saudi Arabia.

7- Abd al-Rahim Ghalib 1988: Encyclopedia of Islamic Architecture (Arabic - French English) Edition

First, Beirut, Gross Press.

8- Fahmy, Hassan Hussein, and others 1966 Production Engineering, 1st floor, The Anglo Egyptian Library, Cairo.

9- Muhammad Ahmad Zahran, Metal Works and Antiques Arts, 1st Floor, Anglo-Egyptian Office, Cairo.

10- Mohy El-Din Talou 1991 Decorative Arts, 2nd floor, Syria, Damascus Publishing House. 11- Mahmoud Al-Bustani 1992 Islam and Art 1st Floor, Cleopet R Building, Beirut, Lebanon. 12- Rogers (J.M.):2010 ,IslamicArt \& Design, London

13- A rseven. C. 2005 " Le metal" Les Art Decoratifs Turcs, Istanbol, 14-Moataz Enad GHAZWAN, INTELLECTUAL AND HISTORICAL REFERENCES AND THEIR REFLECTIONS ON CONTEMPORARY APPLIED ARTS CARPETS AS A

MODEL, International Journal of Multidisciplinary Studies in Art and Technology, Vol. 2, No. 1, 2019, pp. 12-20.

15-Imene M. CHALLOUF, LA PHOTO- UNE PRATIQUE DU SUPPORT (POÏETIQUE 
D’UNE EXPERIMENTATION PLASTIQUE AUTOUR DU SUPPORT

PHOTOGRAPHIQUE), International Journal of Multidisciplinary Studies in Art and

Technology, Vol. 2, No. 1, 2019, pp. 21-31.

16-Yasser BADAWY, METAPHYSICS OF THE UNIVERSE IS A RENEWED INSPIRATION STRATEGY FOR ARTISTIC CREATIVITY WITH SUSTAINABLE THOUGHT, International Journal of Multidisciplinary Studies in Art and Technology, Vol. 2, No. 1, 2019, pp. 32-45.

Received: September 15, 2019

Accepted: November 20, 2019 